\title{
Solomon's Temple, Stonehenge, and Divine Architecture in the English Enlightenment
}

\author{
Tessa Morrison
}

\begin{abstract}
Isaac Newton had a long running interest in Solomon's Temple. For Newton the plan of the Temple was a successor of the ancient Prytanceum, a temple where a sacred fire was kept burning. The plan of the Prytanceum was 'the frame of the world as the true Temple of the great God' and it was the antecedent to all other temples. Newton mentioned in an unpublished manuscript that it would appear that Stonehenge was an ancient Prytanceum and as such the architectural style of Stonehenge was an antecedent of Solomon's Temple. He only mentioned it once but the connection between Solomon's Temple and Stonehenge was made by other significant figures of the English Enlightenment including Inigo Jones, William Stukeley, and John Wood the Elder. This connection was turned into something particularly English.
\end{abstract}

Stonehenge, a prehistoric monument located 13 kilometres north of Salisbury, and the Temple of Solomon, reputed to be the first temple located on the Temple Mount, Jerusalem, would appear to have no connection at all. Yet in the seventeenth and eighteenth centuries four significant figures of the English Enlightenment, Isaac Newton, Inigo Jones, William Stukeley, and John Wood the Elder considered them to be architecturally and spiritually connected. They all believed that divine truths were encoded within the architecture of these structures.

Architectural plans that were encoded with divine truths had been established in 1604 with the publication of In Ezechielem Explanationes et Apparatus Vrbis Templi Hierosolymitani. Initially the book had been a collaborative effort between two Spanish Jesuit priests, Jerome Prado and Juan Bautista Villalpando, but the early death of Prado left the entire project for Villalpando to complete. In Ezechielem Explanationes is a commentary on the Book of Ezekiel in three massive volumes; only the part of the second volume that contains the architectural plans of the reconstruction of the Temple of Solomon, which was destroyed in 587 всE by Nebuchadnezzar II, has endured with time. ${ }^{1}$ Even when it was first printed, the reconstruction of the lost plan was the only part of this large work to make any public impact.

\footnotetext{
${ }^{1}$ Villalpando and Prado, In Ezechielem Explanationes Et Apparatus Urbis Hierolymitani Commentariis Et Imaginibus Illustratus, 3 vols (Rome, 1596-1604), II (1604).
} 
That impact was enormous: in the one hundred and fifty years following its publication there was an avalanche of support, criticism, commentaries, and reconstructions of the Temple of Solomon with very different styles. ${ }^{2}$

One of the reasons that In Ezechielem Explanationes had such an impact was that the Temple of Solomon had a long history in the Christian tradition of representing Heaven. This notion had its origins in the Jewish tradition, which was manifested in the writings of the philosopher Philo of Alexandria in the first century. ${ }^{3}$ From this tradition came the popular medieval image of God as the Supreme Architect and Designer of the universe and equipped with a compass and ruler. The image portrayed God drawing ground plans of the universe. ${ }^{4}$ The Temple of Solomon as a microcosm of the macrocosm, which was the image upon which Villalpando developed his plan of the Temple, was based on the pattern of the Zodiac. This concept of Divine Architect captured the imagination of the Age of Reason's men of science and they continued to produce alternative plans of the Temple well into the eighteenth century.

Another feature that made In Ezechielem Explanationes significant was that the Divine Architect used the norms of architecture to do his planning. According to Villalpando, these norms originated with the building of the God-given plan of the Temple of Solomon but they were not codified, until Vitruvius' De Architectura (c. 75 всE- c. 15 вCE). Villalpando claimed that Vitruvius plagiarized these architectural principles from the ruins of the Temple of Solomon and that he did not derive them from classical architecture as he had claimed throughout the De Architectura. Villalpando's measurements were quantified by scientific means using the principles of architecture that God had devised for the building of the Temple. Vitruvius's work had been neglected after the fall of the Roman Empire but was rediscovered in the Renaissance, ${ }^{5}$ through the commentaries of other theorists from this period -

${ }^{2}$ For example, Agostino Tornielli, Annales Sacri (Lucae, 1610); Louis Cappel, 'Trisagion sive Templi Hierosolymitani triplex delineatio', in Biblia Sacra Polyglotta, ed. Brian Walton, 6 vols (London, 1657), I, 1-12; Nicolaus Goldmann, Architectura Sacra (Breslau, 1611); Johann Bernard Fischer Von Erlach, Entwurff einer historischen Architectur (Vienna, 1721); Constantin L'Empereur, Mishnah sive Legum Mischnicarum liber qui inscribitur Ordo Sacrorum (Amsterdam, 1702).

${ }^{3}$ Philo, 'Allegorical Interpretation', in The Works of Philo, ed. C. D. Yonge (Peabody, MA: Hendrickson, 2004), pp. 25-49; Philo, 'On the Life of Moses', in ibid., pp. 459-90; Philo, 'The Special Laws', in ibid., pp. 534-639.

${ }^{4}$ For a comprehensive list of manuscripts that contain images of God with a compass and ruler, see John Block Friedman, 'The Architect's Compass in Creation Miniatures of the Later Middle Ages', Traditio, 30 (1974), 419-29.

${ }^{5}$ Vitruvius Pollio, The Ten Books of Architecture, ed. M. H. Morgan (New York: Dover, 1960); see also Indra Kagis McEwen, Vitruvius: Writing the Body of Architecture (Cambridge, MA: MIT Press, 2003). 
such as Daniel Leon Battista Alberti (1404-1472), Sebastiano Serlio (14751554), Daniel Barbaro (1514-1570), and Andrea Palladio (1508-1580). De Architectura, through the original and its later commentaries, remains one of the most influential works of architectural history.

This article explores the connections made by Isaac Newton, Inigo Jones, William Stukeley, and John Wood who perceived that the Temple of Solomon and Stonehenge, were connected architecturally and spiritually. While each made this connection in either published or unpublished works, they each had a different conception of this connection between the Temple and Stonehenge. They all considered the Temple to have been built to architectural norms. They also all believed that both the Temple and Stonehenge represented the plan of the celestial universe, which was 'written' into the architecture and embodied by the very stones of the structures.

Villalpando's reconstruction of the Temple stimulated a debate as to the appearance of the Temple that continued for a hundred and fifty years between theologians, scholars, and architects. This debate appears to have been a European debate and its impact seems less visible in England. Nevertheless, it is well known that Newton had an interest in Solomon's Temple, even if he only mentioned it in passing and not in any detail. ${ }^{6}$ Stukeley's work on Stonehenge is also very well known, but his body of research on the Temple of Solomon - a number of unpublished papers that until recently have been difficult to access - has received little attention. ${ }^{7}$ Wood's and Jones's writings on Stonehenge are rarely discussed by scholars and if they are mentioned at all it is only in passing and without any detailed analysis. ${ }^{8}$ My contention, however, revealed through an analysis of Newton's, Jones's, Stukeley's, and Wood's published and unpublished texts, is that the depth of the English debate around the origins of architecture is much more extensive than previously thought ${ }^{9}$ and with the connections to Stonehenge it takes on a very English slant. Stukeley, Jones, and Wood had 'patriotic' ideals of the

${ }^{6}$ The longest discussion - at only just over one page - of Newton's work on the Temple is in Richard S. Westfall, Never at Rest: A Biography of Isaac Newton (Cambridge: Cambridge University Press, 1980), pp. 354-55.

${ }^{7}$ For example, David Boyd Haycock, William Stukeley: Science, Religion and Archaeology in Eighteenth-Century England (Woodbridge and Rochester: Boydell, 2002), pp. 155-56.

${ }^{8} \mathrm{Cf}$. for example, Simon Varey, Space and the Eighteenth-century English Novel (Cambridge, Cambridge University Press, 1990), pp. 95-97.

${ }^{9}$ Claude Perrault, 'Unknown Designs for the "Temple of Jerusalem”, in Essays Presented to Rudolf Wittkower, eds Douglas Fraser, Howard Hibbard, and Milton J. Lewine (London: Phaidon, 1969). 
connections between Stonehenge and the Temple which were later linked to patriotic interpretations. ${ }^{10}$

Of the many manuscripts that Isaac Newton (1642-1727) wrote on the Temple of Solomon over a fifty-year period, there is only one (surviving) that reveals his interest in, and knowledge of, architecture and architectural theory. ${ }^{11}$ This manuscript reveals his knowledge of Vitruvian theory, ${ }^{12}$ contemporary reconstructions of and commentaries on Solomon's Temple, as well as his familiarity with secular and religious ancient texts. ${ }^{13}$ Newton both praises and criticizes Villalpando: he claims that although Villalpando had created the best of the reconstructions of the Temple of Solomon, his reconstruction had many problems. He points to the elements ofVillalpando's design that contradict the biblical description, but strongly agrees with the concept of the Temple as microcosm of the universe. ${ }^{14}$

Like Villalpando's reconstruction of the Temple, Newton's was also based on the Book of Ezekiel, and was constructed with the norms of architecture as specified by Vitruvius. The length of the Hebrew cubit, the unit of measurement with which the Temple was built, was unknown. In addition to his reconstruction, Newton made an extensive study of the Hebrew cubit, in which he used the modern mathematics of the time. ${ }^{15}$ Newton's reconstruction in Babson MS $0434^{16}$ was not a symbolic analysis;

${ }^{10}$ See, for instance, Linda Colley, Britons: Forging the Nation, 1707-1837 (London: Pimlico, 2003).

${ }^{11}$ Wellesley, MA, Babson College Library, MS 0434, Isaac Newton, 'A Treatise or Remarks on Solomon's Temple. Introduction to the Lexicon of the Prophets, Part Two: About the appearance of the Jewish Temple', c. mid-1680s.

${ }^{12}$ Babson, MS 0434, Newton, 'A Treatise or Remarks', fols $29^{\mathrm{r}}, 36^{\mathrm{r}}, 37^{\mathrm{r}}, 45^{\mathrm{r}}$; see also Tessa Morrison, 'The Body, the Temple and the Newtonian Man Conundrum', Nexus: Architecture and Mathematics, 12.2 (2010), 342-52. For further detail of Newton's knowledge of Vitruvian Theory see Tessa Morrison, Isaac Newton's Temple of Solomon and His Reconstruction of Sacred Architecture (Basel: Birkhauser, 2011).

${ }^{13}$ Babson, MS 0434, Newton, 'A Treatise or Remarks', fols 11 $1^{\mathrm{r}}, 22^{\mathrm{r}}, 32^{\mathrm{r}}, 40^{\mathrm{r}}, 47^{\mathrm{r}}, 48^{\mathrm{r}}, 56^{\mathrm{r}}$.

${ }^{14}$ Tessa Morrison, 'Villalpando's Sacred Architecture in the Light of Isaac Newton's Commentary', Nexus 7:Architecture and Mathematics, special issue (2008), 79-91.

${ }^{15}$ Isaac Newton, 'A Dissertation Upon the Sacred Cubit of the Jews', in Miscellaneous Works of Mr. John Greaves, ed. Thomas Birch (London, 1737), pp. 405-33. Newton uses a series of limits of ancient measurement to continually refine his estimation of the cubit. The paper is ingenious, but flawed, since he ultimately has to reject his initial premises in order to fit his estimation into the biblical definition of the cubit.

${ }^{16}$ Another reconstruction of the Temple by Newton, entitled Ancient Kingdoms amended, was posthumously published in 1727 . However, it is the work of an aging Newton, it contains no architectural references, and is a summary of the verses of the Temple from the Book of Ezekiel. The description of the Temple in Ancient Kingdoms amended is brief and shows no relationship to the three architectural plans that accompany the text. The 
rather it was intended to be an accurate reconstruction of the Temple in both its architectural plan and the accuracy of the length of the cubit.

Like his work on the Temple, Newton's work on prophecy was produced over a fifty-year period, but the published work represents only a small portion of the whole. Newton's only published work on prophecy was The Observations upon the Prophecies of Daniel and the Apocalypse of St John, ${ }^{17}$ published posthumously in 1733 by his nephew Benjamin Smith, in two separate English editions, one from London and the other Dublin. The book was assembled from several incomplete manuscripts. Unfortunately, the editor did not include Newton's colourful, descriptive images of the Temple, and the published version is brief and dull when compared to the original manuscripts. The Temple of Solomon was an important key to understanding his prophetic works for Newton claimed that 'the Temple is the scene of the visions ${ }^{18}$ of the prophets. Newton related the actions of the prophecy, of Daniel, Ezekiel and John the Divine, to the architecture and to the spaces within the Temple.

In his unpublished manuscripts Newton described the Temple as more than just a stage:

In the Apocalypse the world natural is represented by the Temple of Jerusalem \& the parts of this world by the analogous parts of the Temple: as heaven by the house of the Temple; the highest heaven by the most holy; the Throne of God in heaven by the Ark; the Sun by the bright flame of the fire of the Altar, or by the face of the Son of Man shining through this flame like the Sun in his strength; the Moon by the burning coals upon the Altar convex above \& flat below like an half Moon; the stars by the Lamps; thunder by the song of the Temple \& lightning by the flashing of the fire of the Altar; the earth by the Area of the courts \& the sea by the great brazen Laver. And hence the parts of the Temple have the same signification with the analogous parts of the world. ${ }^{19}$

All parts of the Temple represented the world, which was a microcosm of the universe and designed by God. The original and pristine religion of Noah was preserved in the Prytanæum, a public building where a sacred fire of the ancient religious sect of the Prytanæ was kept burning. Newton believed

plans are clearly drawn by another hand since the detail in them does not correlate with any of Newton's work on the Temple.

${ }^{17}$ Isaac Newton, Observations, on the Prophecies of Daniel and the Apocalypse of St. John (1733), eds Stephen J. Barnett and Mary E. Mills (Lewiston: Mellen, 1999).

${ }^{18}$ Newton, Observations, p. 259; Cambridge, King's College Library, Keynes MS 3, Isaac Newton, 'Irenicum', undated, fol. 48.

${ }^{19}$ Cambridge, King's College Library, Keynes MS 5, Newton, 'The First Book Concerning the Language of the Prophets', c. mid-1680s, fol. v. 
that the Prytanæ was the original religion of the true God. Within the architectural plan of the Prytanæum was the 'frame of the world as the true Temple of the great God they worshipped'. ${ }^{20}$ When Moses erected his altar and the Tabernacle, he also preserved the religion of his ancestors by placing the fire in the common centre of the court of the Priests 'so as to make it a symbol of the world' ${ }^{21}$ Solomon used the Tabernacle of Moses as a blueprint for his Temple, but doubled its dimensions. This plan resulted in 'framing the Tabernacle \& Temple so as to make it a symbol of the world'. ${ }^{22}$

According to Newton, the ancient Prytanæum could be seen throughout the world, including England.

In England near Salisbury there is a piece of antiquity called Stonehenge which seems to be an ancient Prytanæum. For it is an area compassed circularly with two rows of very great stones with passages on all sides for people to go in and out at. Tis said that there are some pieces of antiquity of the same form \& structure in Denmark. For its to be conceived that the Vestal Temples of all nations as well as of the Medes \& Persians were at first nothing more than open round areas with a fire in the middle, till towns \& cities united under common councils \& built them more sumptuously. In Ireland one of these fires was conserved till of late years by the Moncks of Kildare under the name of Briget's fire \& the Cænobium was called the house of fire. ${ }^{23}$

Newton only mentioned this connection between Stonehenge and the Prytanæum once, but there is no ambiguity in his meaning: he clearly considered that Stonehenge's architectural plan was an ancestor of the plan of the ancient Prytanæum. He made the connection between the Prytanæum and the Temple of Solomon in several manuscripts. ${ }^{24}$ Thus, for Newton, the architectural style of Stonehenge was an antecedent of Solomon's Temple. Unfortunately Newton does not mention how the architectural plan of the round Stonehenge related to the architectural plan of the square Temple precinct, with the exception of there being a central altar in both plans.

${ }^{20}$ Jerusalem, Jewish National and University Library, Yahuda MS 41, Isaac Newton, 'The Original of Religions' ('Draft chapters of a treatise on the origin of religion and its corruption'), undated, fol. $7^{\mathrm{r}}$.

${ }^{21}$ Newton, 'The Original of Religions', fol. 6 '.

${ }^{22}$ Newton, 'The Original of Religions', fol. $5^{\mathrm{r}}$.

${ }^{23}$ Newton, 'The Original of Religions', fol. $3^{\mathrm{r}}$.

${ }^{24}$ For instance, Newton, 'The Original of Religions', Oxford, New College Library, Isaac Newton, 'Drafts of "The Original of Monarchies"', undated; Cambridge, King's College Library, Keynes MS 146, Isaac Newton, 'The Original of Monarchies', undated; Oxford, New College Library, MS 361 (1), Isaac Newton, 'Miscellaneous papers relating to chronology and the "Theologiae gentilis origines philosophicae", undated. 
Stonehenge had featured in the Arthurian legend. In Geoffrey of Monmouth's highly influential History of the Kings of Britain ${ }^{25}$ written in the twelfth century, Merlin had been ordered to erect a monument for the counts and earls that had been slain in the battle between the Britons and the Saxons. Merlin used his artistry to disassemble a stone monument - the boulders so enormous no man alive was capable of moving them - called the Giants' Ring which stood on Mount Killaraus in Ireland. ${ }^{26}$ King Aurelius, Arthur's uncle, ordered Merlin to erect the stones round the burial-place of the fallen warriors in exactly the same way they had been erected in Mount Killaraus. After Aurelius's death, he too was buried inside the Giants' Ring, which was called Stonehenge in the English language. ${ }^{27}$ Edmund Spenser's Faerie Queene also repeats the tale of Briton noblemen being slain and buried at the monument of Stonehenge. ${ }^{28}$ In the first edition of Britannia, originally published in 1586, William Camden gives a brief account of the monument's dimensions and notes its physical deterioration, but it was not until the 1610 edition that it was first illustrated and a selection of descriptions of its origin, including the claims that it was built by Merlin's Magic and that it was built by the early Britons, were added. ${ }^{29}$ In Edmund Gibson's 1695 edition of Camden's Britannia, there were more explanations of its origins added including a Druid origin, ${ }^{30}$ a theory that had been promulgated for some time and had been outlined in detail by John Aubrey in $1648 .^{31}$

A holistic concept of Stonehenge, which included its architecture, its origin, and its meaning, was considered by Inigo Jones (1573-1653) who surveyed it at King James's request in 1620, but this work was not published until 1655, after Jones's death. The Most Notable Antiquity of Great Britain Vulgarly called Stone-Heng on Salisbury Plain Restored was based on notes written by Jones and edited by John Webb. Webb claimed that he had 'moulded off and cast into a rude form, from some few indigested notes of the late judicious

${ }^{25}$ Geoffrey of Monmouth, The History of the Kings of Britain, trans. Lewis G. M. Thorpe (Harmondsworth: Penguin, 1966).

${ }^{26}$ Geoffrey of Monmouth, p. 196.

${ }^{27}$ Geoffrey of Monmouth, p. 262.

${ }^{28}$ Edmund Spenser, The Faerie Queene, ed. Thomas P. Roche (New Haven: Yale University Press, 1978), II, x, 66.

${ }^{29}$ William Camden, Britannia, or A Chorographicall Description of the Most Flourishing Kingdomes, England, Scotland, and Ireland, and the Ilands Adioyning, Out of the Depth of Antiquitie (London, 1610), pp. 252-53.

${ }^{30}$ William Camden, Britannia, ed. Edmund Gibson (London, 1695), p. 95.

${ }^{31}$ John Aubrey, Monumenta Britannica; or, a Miscellany of British Antiquities (1648; Sherborne: Dorset, 1982). This work remained unpublished until the twentieth century. 
architect, the Vitruvius of his age, Inigo Jones' ${ }^{32}$ However, it is not really clear how much of the book was by Jones and how much was by Webb. The 'few indigested notes' no longer exist nor is it known if these notes were written in the 1620 s or later in Jones's life. Drawings, architectural plans, and heavily annotated books of Jones exist but none of his writings has survived. The Most Notable Antiquity was not well received. Indeed, it was highly criticized and ten years later, in an attempt to silence his critics, Webb published a justification for it. ${ }^{33}$ The chief critic of the work was Walter Charleton, King Charles II's doctor, who openly attacked Jones's interpretation of Stonehenge and gave Stonehenge Danish origins. ${ }^{34}$

Jones created a reconstruction of Stonehenge, which had little relation to the existing ruins of Stonehenge, with four equilateral triangles within a circle, these overlaying equilateral triangles that formed a four-sided tetragon and the six 'columns' in the centre that formed a hexagon (see Figure 1). For Jones,

Now this Antiquity consisting of several stones, orderly disposed into one entire work, in imitation, as it were, of those several stars which appearing to us in the heavens in the form of a circle, are called the celestial crown; and wholly designed by those schemes wherewith astrologers use to describe celestial bodies. ${ }^{35}$

According to Jones, Cælus the god of the sky was worshipped at the Temple of Stonehenge, through sacrifices that were performed around a fire. The significance of the fire was reflected in the structure of the columns or upright stones, 'all the upright stones in this Antiquity are pyramidal like flames, in imitation of those ethereal fires, wherewith the heaven is adorned' ${ }^{36}$ The architectural scheme that Jones presents is classical in nature and is the same architectonical scheme of the stage of a theatre that is presented in Book Five, ChapterVI of Vitruvius's De architectura. ${ }^{37}$ Jones's concept of this ancient 'temple' at Stonehenge parallels Newton's concept of the Prytanæum, in that the centres of both represented the sacred fires that adorned the heavens. Furthermore, Jones related his architectonical scheme to the Temple of

\footnotetext{
${ }^{32}$ Inigo Jones, The Most Notable Antiquity of Great Britain Vulgarly called Stone-Heng on Salisbury Plain Restored (London, 1655), Preface, unpaginated.

33 John Webb, A Vindication of Stone-Heng Restored (London, 1665).

${ }^{34}$ Walter Charleton, Chorea Gigantum (London, 1665).

${ }^{35}$ Jones, Most Notable Antiquity, p. 106.

${ }^{36}$ Jones, p. 105.

${ }^{37}$ Vitruvius, Ten Books of Architecture, pp. 129-63.
}

Parergon 29.1 (2012) 
Solomon. This scheme is one that the astrologers used to describe the celestial bodies:

being all jointly made use of by the architect for conformation of this sacred structure, it is not impossible Stonehenge was so composed, because dedicated to Cælum. Yea further, (if lawful to compare an idolatrous place with so divine a work) was not the Temple of Jerusalem adorned with the figures of Cherabim, that thereby the Nations of the Earth might know it was the habitation of the living God? And, why not in this manner this temple composed by astrological figures, that after Ages might apprehend, it was anciently consecrated to Cælus or Cælum Heaven $?^{38}$

This astrological scheme was built into the stone of the architecture and it was patterned after the universe - it was a microcosm of the macrocosm - it was the image of the universe in miniature. Stonehenge and the Temple of Solomon both had celestial implications.

While Jones does not mention Villalpando in his book on Stonehenge, he was probably aware of his work. James I and Charles I both had a strong interest in the Temple of Solomon and in Villalpando's work: both studied the Temple and Spanish architecture with a view to planning a new palace, and a copy of In Ezechielem Explanationes bearing James I's arms on the binding belonged to the Royal Library. ${ }^{39}$ As Royal architect, Jones was undoubtedly involved in their various discussions and plans. How much influence Villalpando had on Jones is impossible to say but the Temple and the celestial connection had similarities in the works of both men.

Jones claimed that Stonehenge had an obvious geometric and harmonious structure but he was quick to dismiss the idea that Stonehenge was built by the ancient Britons for the Druids. According to Jones, the Druids lived a contemplative life 'without art, without order'. ${ }^{40}$ For Jones, Stonehenge's beautiful proportions were evidence of England's Classical past, and not the rude dwellings of the native Britons. The manner of the buildings of the ancient Britons Jones found 'so far short of the magnificence of this antiquity, that they were not stately, nor sumptuous; neither had they anything of order, or symmetry, much less, of gracefulness and decorum in them'. ${ }^{41}$ Stonehenge, Jones asserted, was built with the knowledge of the arts and sciences 'with much art, order and proportion't2 and these Britons were

${ }^{38}$ Jones, p. 107.

${ }^{39}$ Roy Strong, Britannia Triumphans: Inigo Jones, Rubens and Whitehall Palace (Hampshire: Thames and Hudson, 1980), p. 61.

${ }^{40}$ Jones, p. 3.

${ }^{41}$ Jones, p. 11.

42 Jones, p. 65. 
ignorant of this knowledge before the Romans arrived. However, from the architecture of Stonehenge, the Britons had learnt true principles of Classical architecture; even though it was not of British invention, the Tuscan order, the plainest and oldest of the classical columns, became representative of the civilized Britons. Jones himself used all of the orders in his architecture, which can be seen in the facade of the Banqueting House, London, but his elegant use of the Tuscan order can still be seen in the portico of St Paul's Church, Covent Garden.

Antiquarian William Stukeley (1687-1765) made the connection between Solomon's Temple and Stonehenge more explicit and far more patriotic than Jones. According to Stukeley, the architecture of Stonehenge was not an architectural civilizing influence but it was an architectural predecessor of Solomon's Temple, and thus the Britons had knowledge of the very origins of architecture. Stukeley is best known for Stonehenge, a Temple Restor'd to the Druids (1740) and A[ve]bury a Temple of the British Druids (1743). The field trips for his work on Stonehenge and Avebury were carried out twenty years before the publication of these works and at the same time he was working on a manuscript entitled 'The Creation, Music of the Spheres K[ing] S[olomon's] Temple Microco[sm] - and Macrocosm Compared \&C' . ${ }^{43}$ In this fascinating, but largely ignored, manuscript he claims that the account in Genesis of the Creation of the universe was 'a truthful and philosophical history of the origin of all things' ${ }^{44}$ This includes the origin of architecture that he firmly placed on the fourth day of creation. The glories of nature, such as stone, trees, and forests, had a divine origin and were invented by the maker of the world, resulting in the creation of the arts and architecture. ${ }^{45}$

According to Stukeley the sacred oak groves and the religion of the Druids were directly connected to Abraham and the

earthly Tabernacle, was a house, to be honoured with the presence of the supreme, the invisible deity! So that the deity himself may here be said literally, to dwell in a wood or grove; as formerly in that famous oak grove of Beersheba, planted by the illustrious patriarch, and first Druid, Abraham: and from whom our celebrated British Druids came; were of the same patriarchal, reformed religion; and brought the use of sacred groves, to Britain. ${ }^{46}$

${ }^{43}$ London, Freemasons Library, William Stukeley, 'The Creation, Music of the Spheres K[ing] S[olomon's] Temple Microco[sm]- and Macrocosm Compared \&C, 1721-24'.

${ }^{44}$ Stukeley, 'Creation', p. 5.

${ }^{45}$ Stukeley, 'Creation', p. 31.

${ }^{46}$ Stukeley, Palaeographia sacra, or, Discourses on Monuments of Antiquity that Relate to Sacred History (London, 1736), pp. 7-8. 
This led Stukeley to outline the natural development of architecture that was related to the Scriptures. He developed a chronology leading up to the architectural plan for the Temple of Solomon as

I. The round form, like our Stonehenge \& innumerable more, appropriate to the public Solemnity of the vernal equinox (see Figure 2).

II. The Alate temple, circle \& wing, dedicate[d] to the summer solstice festively, such as that at Barrow Lincolnshire on the banks of the Humber[,] another at Navestock on Epping Forest (see Figure 3). III. The consecrated oak grove, the only Temple of Homer, from Abraham. These belong to the public sacrifice of the autumnal Equinox. Such [is] the practice of the British Druids.

IV. The Dracontium temple, or snake transmitted through a circle, assigned to the sacred panegyric of the winter solstice, such [as] our Abury in Wiltshire, \& Shap in Cumberland (see Figure 4).

V.The covered temple of the Mosaic tabernacle, such [as] the Antrum Nympharum \& Ithaca, the Mithriae caves of Persia.

VI. Solomon's Temple, the original of all ancient covered Temples. ${ }^{47}$

Like Newton, Stukeley promulgated the idea that Stonehenge was an antecedent of Solomon's Temple.

Stukeley's survey was undertaken between the years 1721 and 1724 and was documented in an unpublished manuscript. ${ }^{48}$ It demonstrates the precision of his study of the monument as it was executed with architectural accuracy. The ground plan from his survey (Figure 5) was the most detailed and precise plan of Stonehenge of its time and from it, he developed a reconstruction of Stonehenge (see Figures 6 and 7). In Stonehenge, a Temple Restor'd, he presented illustrations that showed sections and elevations of Stonehenge in its present ruined form and as he believed it to have been in its original form. The ground plan of this survey was not published in Stonehenge, a Temple Restor'd; this later left him open to criticism for not demonstrating that he had undertaken a survey of the layout or plan of the existing ruins of Stonehenge. This criticism suggested the reconstruction that Stukeley was presenting was just fanciful and meaningless drawings. ${ }^{49}$

Stukeley strengthened the connection between Stonehenge and Solomon's Temple through the examination of the measurements of each structure. He claimed that Stonehenge had been built in Hebrew cubits,

${ }^{47}$ London, Freemasons Library, William Stukeley, 'The Order of the Pillars of Solomon's Temple', 1760, fol. 7.

${ }^{48}$ Aubrey Burl and Neil Mortimer, eds, Stukeley's Stonehenge:An Unpublished Manuscript 17211724 (New Haven:Yale University Press, 2005).

${ }^{49}$ John Wood, Choir Gaure, Vulgarly called Stonehenge on Salisbury Plain, Described, Restored and Explained (London, 1749), p. 35. 
'being the measure us'd by the Druids'. ${ }^{50}$ To demonstrate that the Hebrew or Druid cubit, as Stukeley later called it, was the measurement of Stonehenge he claimed that all the measurements he had taken in his survey fitted into even numbers and fractions of cubits. Although he claimed in his diary to have taken two thousand measurements, ${ }^{51}$ there is no complete record of them in his field notes. Stukeley defined the cubit as being six palms in length. However, the actual length of the ancient Hebrew cubit is a puzzle that had been studied and contested by many, including Newton, who estimated the cubit of six palms to be 2.068 English feet or 24.816 English inches. ${ }^{52}$ Stukeley claimed that the ancient cubit was 20.8 English inches,${ }^{53}$ but some of his calculations were muddled. ${ }^{54}$ In addition, he claimed that the diameter of Stonehenge was sixty cubits, the same measurement as the interior length of the Temple of Solomon. ${ }^{55}$

In 'The Creation', Stukeley also reconstructed Solomon's Temple. He adds a tower, used not only as a watchtower but also for taking astrological observations that enabled the correct dating of ritual observances, such as Passover, every year. Stonehenge had a similar dating astrological purpose. Stukeley was the first to recognize the astronomical axial alignment of Stonehenge. He claimed that the avenue of Stonehenge is positioned

to the principal line of the whole work, the north-east, where about the sun rises, when the lays are longest. ... The principal diameter or groundline of Stonehenge, leading from the entrance, up the middle of the temple, to the high altar, (from which line the whole work is formed) varies about that quantity southward of the north east point. The intent of the founders of Stonehenge, was to set the entrance full north east, being the point where the sun rises, or nearly, at the summer solstice. ${ }^{56}$

According to Stukeley, the summer solstice was the time that the Druids celebrated one of their principal religious festivals. Like Stukeley's tower of

${ }^{50}$ William Stukeley, Stonehenge, a Temple Restor'd to the British Druids (London, 1740), p. 15.

${ }^{51}$ William Stukeley, The Family Memoirs of the RevWilliam Stukeley MD and the Antiquarian and Other Correspondence of William Stukeley, Roger and Samuel Gales Etc, Surtees Society, 30 (Durham: Andrews, 1882), p. 249.

52 Newton, 'Sacred Cubit of the Jews', p. 429.

${ }^{53}$ Stukeley, Stonehenge, a Temple Restor'd, p. 6; Burl and Mortimer, eds, Stukeley's 'Stonehenge', p. 22.

${ }^{54}$ For instance, he later stated that the diameter of 60 cubits was 102 feet, which would make the cubit 20.4 inches, see Stukeley, Stonehenge, a Temple Restor'd, p. 15.

55 Stukeley, Stonehenge, a Temple Restor'd, p. 15.

56 Stukeley, Stonehenge, a Temple Restor'd, pp. 35, 56.

Parergon 29.1 (2012) 
the Temple of Solomon, Stonehenge was designed to measure astrological observations and to mark the time of ritual observances.

While Stukeley's chronology of architecture is significant, Stukeley's contribution to architecture, with the exception of Stonehenge, is rarely acknowledged. David Boyd Haycock, Stukeley's biographer, mentions Stukeley's interest in Solomon's Temple but does not mention the chronology or the significance of the Temple in Stukeley's works. ${ }^{57}$ Like Newton's, Stukeley's reconstruction of the Temple of Solomon was constructed with the norms of architecture that had been codified by Vitruvius. However, Stukeley was convinced that Stonehenge was also constructed to these norms. For Stukeley, the Druid 'priest knew nothing of Vitruvius; they deduc'd this knack from an authority much ancienter than him, viz, from pure natural reason, and good sense'. ${ }^{58}$ In Stukeley's chronology, the ancient Druids possessed ancient knowledge which was, unbeknown to them, codified by Vitruvius, lost, and then rediscovered to become the wisdom of the new age. Stukeley searched for the lost knowledge of the ancients and, in 1721, he claimed that it was out of curiosity to learn these secrets of the ancient rituals and mysteries that he had joined the Freemasons. ${ }^{59}$ He became a staunch Freemason all his life and he founded a lodge at Grantham in Lincolnshire in 1726 after leaving London. ${ }^{60}$ The rediscovery of ancient knowledge was a central theme of Stukeley's work, and the Temple was at the centre of it all. In this search for lost knowledge he studied the work of Villalpando.

In his unpublished works, Stukeley claimed that Villalpando had examined the sumptuous architecture of the Temple in his book which was the most complete and perfect example of the Temple produced at the time. However, Stukeley also claimed that his design had not 'hit the white' (meaning that Villalpando's plan of the reconstruction of the Temple was not the correct one $)^{61}$ and he continued to criticize Villalpando throughout his reconstruction.

Although Stukeley does mention the Druids as the builders of Stonehenge in his 1720s study, his emphasis then was more on its architecture and measurements. By the time Stonehenge, a Temple Restor'd was published in 1740, Stukeley had shifted his focus to the Druids, and in describing them as the

\footnotetext{
${ }^{57}$ Haycock, William Stukeley, pp. 155-56.

${ }^{58}$ Stukeley, Stonehenge, a Temple Restor'd, p. 35.

${ }^{59}$ William Stukeley, The Commentarys, Diary, and Common-Place Book and Selected Letters of William Stukeley (London: Doppler Press, 1980), p. 54.

${ }^{60}$ Robert Freke Gould, The History of Freemasonry: Its Antiquities, Symbols, Constitutions, Customs, Etc. (1885; Whitefish, MT: Kessinger, 2003), p. 284.

${ }^{61}$ Stukeley, 'Creation', p. 74.
} 
retainers of ancient knowledge of the architecture, they became increasingly popular with the public. Stukeley wrote so much about the Druids that he became known as the 'Arch Druid'. Fifteen years after Stukeley's death, Henry Hurle formed The Ancient Order of the Druids - a charitable association and offshoot of the Freemasons - which is still in existence today. ${ }^{62}$ This association was highly influenced by Stukeley and affirmed the same principles and rituals of the Druids as did Stukeley.

Architect John Wood the Elder (1704-54), was a strong critic of Stukeley; he criticized Stukeley's details of the plan of the Temple, of Druid culture, and his seeming lack of architectural knowledge. He described Stukeley's reconstruction of Stonehenge as a 'work that never existed unless in Jones's and Stukeley's imagination'. ${ }^{63}$ Although Wood was critical of Jones's reconstruction, his main attack was directed towards Stukeley's work on the Temple. Wood's visionary architecture transformed the city of Bath into the Jewel in the Georgian crown. He was also a prolific writer and a very keen historian who published works on the History of Bath, the origins of architecture, the classical orders, and Stonehenge.

An Essay Towards a Description of Bath was first published in 1749 in two volumes. In the first volume, Wood examined the details of Bath's history and development. In the second volume he considered 'modern' Bath, and gave a description of his role in the development of the city of Bath in the 1720s and 1730s. Wood acknowledged the Roman contribution to Bath, but gave greater emphasis to the ancient Britons' role. He played down the Romans' role because he regarded it as incidental to Bath's development, which had been a city of importance since its foundation by the legendary British King Bladud.

Bladud was first mentioned in Geoffrey of Monmouth's History of the Kings of Britain,${ }^{64}$ the oldest source for Bath's foundation myth. The myth had variations, but generally it is said that after contracting leprosy Prince Bladud was banished from his father's kingdom. He had to make a living as a swineherd until some of the pigs caught leprosy from him. Bladud fled from his employer with the pigs until he found some hot mud that ultimately cured them. He returned to his father's court where his position was reinstated and he eventually became a wise ruler. He founded the city of Bath, where he had found the hot mud, and built the temple of Aqua Sullis dedicated to the goddess Minerva. By the seventeenth century, this was the generally accepted

\footnotetext{
${ }^{62}$ See the Ancient Order of Druids' website at <http://www.aod-uk.org.uk/home.htm>, accessed 22 February 2010.

${ }^{63}$ Wood, Choir Gaure, p. 30.

${ }^{64}$ Geoffrey of Monmouth, History of the Kings of Britain, pp. 80-81.
}

Parergon 29.1 (2012) 
version of Bath's foundation. In Description of Bath, Wood demonstrated that Bladud was the eighth or ninth king of Britain and descended from Brutus, the Trojan prince who settled Britain after the fall of Troy. According to Wood, Bladud had travelled to Greece and learnt the teachings of Zoroaster. He also claimed that Bladud was a colleague and friend of Pythagoras who brought back to Britain the Pythagorean philosophy of numbers and elements, and that it was Pythagorean philosophies that instructed the Britons in the liberal arts and sciences. ${ }^{65}$

Wood noted that the remains of temples surrounding Bath indicated that Bath was the metropolitan seat of the learned sect of the Druids. Wood added the Druid connection to the myth of Bladud. The mysteries of the Druids, Wood claimed, had been brought back from Greece with Bladud, who established Bath as a centre for the Druids and was an Arch Druid himself. The temples of the Druids were built as stupendous models of the Pythagorean planetary system that were used to study and celebrate the heavenly system. ${ }^{66}$ These complex ideas were important to Wood's philosophies and theory of the origins of architecture.

In 1741, Wood published The Origin of Building or the Plagiarism of the Heathens Detected. The main premise of this book is that the norms of architecture that were codified by Vitruvius in De architectura were not derived from the ancient Greeks as Vitruvius had claimed. This claim mirrored that of Villalpando, although Wood does not mention or cite him. However, Wood rarely cited or acknowledged any author in his work. The ancient Greeks, Wood alleged, had plagiarized Jewish architecture and the pinnacle of that architecture was the Temple of Solomon. Wood described the Temple Precinct and supplied a ground plan (Figure 8). The plan is immediately and visibly different from most plans of the Temple precinct derived from the Scriptures. First, Wood's plan of the precinct is rectangular, not square as it is described in the Scriptures ${ }^{67}$ with the exterior wall of the precinct measuring 500 cubits by 840 cubits. Second, he included the outer wall of the Second Temple, which he measured to be 644 by 985 cubits, which is not mentioned by anyone else. Of these measurements, only the 500 cubits had a biblical precedent, and the other measurements were larger than the area of the Temple mount, Mount Moriah. ${ }^{68}$ Third, although the inner

${ }^{65}$ John Wood, An Essay Towards a Description of Bath, 2 vols (London, 1749), I, 7-40.

${ }^{66}$ Wood, Description of Bath, I, 148; Wood, Choir Gaure, p. 11.

${ }^{67}$ According to Ezekiel 42. 20, the exterior wall of the Temple was 500 by 500 cubits.

${ }^{68}$ W. D. Davies and Louis Finkelstein, eds, The Cambridge History of Judaism, 4 vols (Cambridge: Cambridge University Press, 1984-2006), III: The Early Roman Period, eds William Horbury, W. D. Davies, and John Sturdy (1999), p. 43. 
court is a double square, instead of being 100 by 200 cubits - double the measurements of Moses' Tabernacle - it is 340 by 680 cubits, which also has no biblical precedent.

Wood claimed that the Temple and its precinct were 'beyond imagination itself' ${ }^{69}$ The splendour and the majesty of the Temple were awe-inspiring:

The Temple being supposed to have represented the universe, the entablature round the inside of the structure may be conceived to have intimated the division between heaven and earth; the lights, those of the firmament; and all the plain surface of gold, that beautiful and terminate view a clear day exhibits to the eye: the cherubim above, and the pillars below, represented the inhabitants of heaven, and those of the earth; the first in their real shapes, the last hieroglyphically. ${ }^{70}$

While the structure of the Temple was the universe itself, Wood took the measurements of the Temple to be monuments to biblical events. The porch's height of 120 cubits was in memory of the deluge. The 400 pomegranates in four rows on the capitals represented the number of years from the birth of Isaac to the end of the bondage of God. The seven wreaths of chain work, circumscribing the seven nets of chequer work in the chapiter (the capital of a column) of each of the pillars, corresponds with the seven days of the victory God gave the Israelites and to the total overthrow of the Pharaohs who were swallowed by the Red Sea. ${ }^{71}$

The number of pillars and the measurements of the court of Wood's Temple also reflected historical events. The inward court was built with three rows of hewn stones and a row of cedar beams. Wood calculated the number of columns around this court to be 408, which represented the number of years from the Israelites coming out of Egypt to the time of Solomon beginning the Temple. Wood claimed that the number of pillars in 840 cubits commemorates the number of years from when Solomon began the Temple to the birth of Christ. ${ }^{72}$ According to Wood, Solomon's Temple was not only a divine piece of architecture, it was also a divine piece of history that encoded events into its numbers and measurements. The Temple not only retained this divine history in its architecture but it symbolized the universe and its workings. The Temples of the Druids and the Christian churches were 'founded on one and the same plan, and both had their origin from Jewish

${ }^{69}$ John Wood, The Origin of Building or, the Plagiarism of the Heathens Detected (Bath, 1741), p. 123.

${ }^{70}$ Wood, Origin of Building, p. 124.

${ }^{71}$ Wood, Origin of Building, pp. 122-23.

${ }^{72}$ Wood, Origin of Building, pp. 127-28.

Parergon 29.1 (2012) 
works' ${ }^{73}$ This plan of the universe, Wood argued, is reflected in the plan of Stonehenge.

Unlike Newton and Stukeley, Wood does not claim that the architectural style of Stonehenge is an antecedent of the Temple of Solomon - in fact he claimed the opposite. Like Stukeley before him, Wood executed an accurate survey of Stonehenge. Unlike Stukeley though, he recorded every detail of his survey in Choir Gaure,Vulgarly called Stonehenge on Salisbury Plain, Described, Restored and Explained, published in 1747. Comparing Stukeley's and Wood's reconstructions (Figures 6 and 10), there is an overall similarity but there are differences in the detail. From his survey, Wood also reconstructed Stonehenge and its resulting ground plan (see Figure 9) is also very similar to Stukeley's. Both of their ground plans are extremely accurate, when compared to modern ground plans of Stonehenge and they highlight the destruction caused to the monument in the intervening twenty years between the surveys of Stukeley and Wood, which was caused mainly by souvenir hunters chipping off pieces of stone. ${ }^{74}$ Wood, however, essentially disagreed with Stukeley on every point, and he criticized him at every turn throughout Choir Gaure. Wood also placed Stonehenge into a historic context that justified his reconstruction.

According to Wood, Bladud set up a university at Stanton Drew, ${ }^{75}$ a stone circle ten miles west of Bath which he dated to 480 все. In the course of his travels through Greece and being a friend and colleague of Pythagoras (who had introduced Jewish architecture to the Greeks), Bladud had learnt the norms of Jewish architecture, and subsequently he introduced them to the Britons. The Temple at Stanton Drew (circle D, Figure 11) which Wood claimed was principally dedicated to the Moon and used by the Druids to catalogue their astronomical knowledge, was built by the Druids in the image of the Second Temple of Jerusalem. ${ }^{76}$ Stonehenge was built in the same style as the circle D of Stanton Drew. Thus its architectural style was an ancestor of the Second Temple of Jerusalem.

The temples of the Druids, like Stanton Drew and Stonehenge, were built as stupendous models of the Pythagorean planetary system, and used to study and celebrate the heavenly system. The two outward rows of pillars are representative of the two revolutions of the Moon, the first of thirty days and the second of twenty-nine days. The founder of the Druids, Bladud, had instructed the Britons in the liberal arts and sciences, and had made models of the Pythagorean planetary system. He had encoded these principles into

\footnotetext{
73 Wood, Origin of Building, p. 221.

${ }^{74}$ Rosemary Hill, Stonehenge (London: Profile, 2008), p. 127.

75 Wood, Description of Bath, I, 148.

76 Wood, Description of Bath, I, 156.
} 
the architecture of the Druid temples. In Choir Gaure, Wood addressed the Earl of Oxford to explain the Pythagorean symbolism of Stonehenge and in it he refers to his reconstruction (see figure 10). The first circle has thirty stones and the second twenty-nine stones representing the length of the lunar months. Wood marked the interval of every second stone from the ones numbered 4 to 27 with the numbers I-XII (indicating the number of the month) and the seven stones in the front, not marked with a Roman numeral, represented 'the seven intercalatory months to bring the revolution of the moon about the earth to an agreement with the revolution of the earth about the sun'. ${ }^{77}$ The pillars of the third row represented one of the decads of days the months are divided into. Four of the pillars refer to the four quarters of the Moon, as well as the sides of the tetrahedron that presented the element of fire, and the remaining six pillars represented the six days of the Moon's age. The nineteen stones of the fourth row represented the lunar years as in the cycle calculated by Meton in 432 все. ${ }^{78}$ The meeting that the ancients called the Harmony of the Spheres 'was celebrated by the British Druids at the end of every nineteenth revolution of the Earth about the sun; and at the end of every two hundred and thirty-fifth revolution of the moon about the earth'. ${ }^{79}$

There are two different colours in the stones of Stonehenge and these intimate good and evil, as well as day and night. Every stone, angle, alignment, and number was symbolic of the Pythagorean system of the movement of the heavens. Wood concluded his emblematical enquiry believing that he had satisfactorily proved that Stonehenge was beyond any doubt a solar, but more particularly a lunar, temple and a work of the British Druids.

The Circus in Bath is one of Wood's finest buildings. It comprises three crescents of three-storey houses arranged in a circle, and around the entire building is a carved frieze. This frieze consists of a strange mix of apparently unrelated ancient symbols of nature, some of which are Masonic, leading various scholars to speculate that Wood was a Freemason. ${ }^{80}$ There is no

77 Wood, Choir Gaure, p. 85.

${ }^{78}$ Alexander Philip, The Calendar: Its History, Structure and Improvement (Charleston, SC: Bibliolife, 2009), p. 43. The term 'Metonic Cycle' is properly applied to the cycle of nineteen twelve-months reinforced by seven intercalary months.

${ }^{79}$ Wood, Choir Gaure, p. 87.

${ }^{80}$ James Stevens Curl, The Art and Architecture of Freemasonry (London: Batsford, 1991); James Steven Curl, Georgian Architecture (London: David and Charles Book, 2002), p. 43; Hazel Conway, Understanding Architecture: An Introduction to Architecture and Architectural History (New York: Routledge, 1994), p. 3. 
reason to disbelieve that he was a mason but there is no proof of this. ${ }^{81}$ It seems unlikely that Wood, who spent a lifetime searching for meaning in ancient monuments and measurements, would design a meaningless frieze, but since he left few letters and no diaries, the meaning must remain the subject of speculation. Wood's legacy is not his writings, which have remained relatively ignored, but rather his architecture. Although he dabbled with the occasional Masonic symbol, ${ }^{82}$ the main influences on his architecture were his studies of ancient monuments like Stanton Drew and Stonehenge. $\mathrm{He}$ strove to replicate the elements of these ancient monuments in his Georgian architecture. ${ }^{83}$ In his book on the classical orders, he described the orders and their proportions in the manner of Vitruvius. However, he gave the orders of architecture Jewish origins, and like Stukeley, he invested the Druids with knowledge of these ancient origins which they possessed before the arrival of Romans in Britain.

These four views on the connections between the Temple and Stonehenge differ in many aspects. However, they all considered that the Temple and Stonehenge were architecturally linked and that both contained divine knowledge within their respective architectures. Newton perceived that the plan of the Temple of Solomon was a successor to the ancient Prytanæum, with the sacred fire burning in its centre representing 'the frame of the world as the true Temple of the great God' ${ }^{84}$ Stonehenge was also one of these microcosms of the macrocosm. These microcosms presented a universe that was round and symmetrical, but since it was Newton who had proved that the orbits of the planets are elliptical, ${ }^{85}$ he clearly did not perceive the Prytanæum or Temple as real maps of the universe that reflected nature but rather saw them as hieroglyphs of the prophets of natural philosophy. Newton does not mention the Druids in any of his surviving papers and it does not appear that Stonehenge was significant to him in itself. To him, it was merely an example of

${ }^{81}$ Tim Mowl and Brian Earnshaw, John Wood:Architect of Obsession (Huddersfield: Millstream, 1988), p. 89. In addition, the author has checked the Freemasons' membership lists in the Grand Lodge, Greater Queen St, London, and there is no evidence that Wood was a member of the Freemasons.

${ }^{82}$ For instance, the Tyberton altar in the church of St Mary in Herefordshire has a Masonic symbol.

${ }^{83}$ Tim Mowl, 'Prehistory and Palladian: John Wood's King's Circus, Bath', in New Light on English Palladianism: Papers Given at the Georgian Group Symposium London, ed. Charles Hind (London: Georgian Group, 1988), pp. 31-49 (p. 31); Mowl and Earnshaw, John Wood, p. 181.

${ }^{84}$ Newton, 'The Original of Religions', fol. $7^{\mathrm{r}}$.

${ }^{85}$ Isaac Newton, Mathematical Principles of Natural Philosophy, trans. Andrew Motte and Florian Cajori (Chicago: Encyclopædia Britannica, 1955), proposition 1. 1, p. 406. 
an ancient Prytanæum, but he had, nevertheless, established the architectural connection between the Prytanæum and the Temple in several manuscripts. ${ }^{86}$ Although the Temple of Solomon was the ancestor of Stonehenge, Newton claimed that the ancient Prytanæum was not the beginning of architecture. He claimed that there had been no mention of the trade of carpenters or good architecture before Solomon sent a request to Hiram the King of Tyre to supply him with such artificers ${ }^{87}$ Newton confidently stated that, 'I meet no mention of sumptuous Temples before the days of Solomon' ${ }^{88}$ It was the Temple of Solomon that was the blueprint for all others; Newton regarded the Kingdom of Israel as the first cultured civilization. The Temple was not only the beginning of cultured civilization that retained ancient knowledge and wisdom, it was also a blueprint for biblical prophecy.

There is no mention or any record that Jones ever carried out a survey of Stonehenge and from his reconstructed plans it would appear that it was unlikely that he did. Jones's astrological scheme of Stonehenge bears no resemblance to the ruined remains of Stonehenge. By creating his classical layout with Tuscan columns, Jones missed the celestial alignment of Stonehenge. Nevertheless, he perceived that Stonehenge was a celestial microcosm built for the Roman God of Heaven. Jones's connection of the Temple and Stonehenge is curious and rather hesitant; he wondered if it was 'lawful to compare an idolatrous place with so divine a work' ${ }^{89}$ Of the four men, Jones is the only one that did not reconstruct Solomon's Temple, so it is impossible to know if he would have applied a similar astrological scheme to the Temple. Still, he made the connection spiritually, if not architecturally.

Stukeley was very critical of Jones's Most Notable Antiquity, claiming that 'It is very disagreeable to me that I was forc'd to combat against a book published in the name of the celebrated Inigo Jones, for whose memory I have the greatest regard ... But it appears very evident to me, that Inigo Jones has little or no part in that work'.$^{90}$ Throughout his work on Stonehenge, Stukeley attacked Webb as if the book had nothing to do with Jones. How much of the book was Jones and how much was Webb is a reasonable question, particularly since Webb admitted he was working with Jones's 'notes'. Yet it should not be surprising that Jones - known as the 'British Vitruvius' ${ }^{11}$

\footnotetext{
${ }^{86}$ See references in $n .24$.

${ }^{87}$ Newton, The Chronology of Ancient Kingdoms Amended (London, 1728), pp. 212-13.

${ }^{88}$ Newton, The Chronology of Ancient Kingdoms Amended, p. 221.

${ }^{89}$ Jones, Most Notable Antiquity, p. 107.

${ }^{90}$ Stukeley, Stonehenge, a Temple Restor'd, Preface, unpaginated.

${ }^{91}$ Curl, Georgian Architecture, p. 27; Vaughan Hart, Art and Magic in the Court of the Stuarts (London: Routledge, 1994), p. 124.
} 
- would desire a Vitruvian solution to the origins of one of Britain's most mysterious monuments.

In his published works of Stonehenge, a Temple Restor'd and Abury a Temple of the British Druids, where he examined the Druid cubit and architectural chronology, Stukeley developed a clear architectural connection between Stonehenge and the Temple of Solomon. The celestial connection was discussed, but remained unpublished in 'The Creation'. Stukeley was one of Newton's first biographers ${ }^{92}$ and he related how at Christmas time in 1725 he had discussed Solomon's Temple with Newton. While they discussed the development of the architectural orders of the Temple, ${ }^{93}$ Stukeley makes no mention of discussing the connection between Stonehenge and Solomon's Temple with Newton, even though Newton had already made this connection in his unpublished works on Stonehenge and Solomon's Temple. Since Stukeley was always keen to demonstrate Newton's agreement with his theories it would appear unlikely that they ever discussed the connection. Nevertheless, whether Newton and Stukeley discussed this connection or not, Stukeley established a full chronology of the Temple's development and the origins of architecture while Newton only regarded it as the antecedent of the architecture.

Although Wood was aware and critical of Jones's and Stukeley's work on Stonehenge, the connection he drew between Stonehenge and the Temple of Solomon was derived from his history of Bath. Wood had extended the traditional myth of King Bladud of Bath to make him the founder of the Druids who had instructed the Britons in the liberal arts and sciences, and had made models of the Pythagorean planetary system. He had encoded these principles into the architecture of the Druid temples, itself a direct ancestor of the Second Temple, which according to the Bible was built on the foundations of Solomon's Temple. Wood reversed the architectural chronology of the Temple and Stonehenge from Newton's and Stukeley's theories. However, all three claimed the origin of the architectural style of Stonehenge was from Jewish architecture. All four authors connected the Temple and Stonehenge spiritually and celestially as being plans of the universe.

While Villalpando's influence is generally seen as European with little English impact, ${ }^{94}$ it can clearly be seen in the unpublished writings of Newton 92 William Stukeley, Memoirs of Sir Isaac Newton's Life (1752; London: Taylor and Francis, 1936).

${ }^{93}$ Stukeley, Memoirs of Sir Isaac Newton's Life, p. 18.

${ }^{94}$ Sergey R. Kravtsov, 'Juan Buatista Villalpando and Sacred Architecture in the Seventeenth Century', Journal of the Society of Architectural Historians, 3 (2005), 312-39; Alberto Pérez-Gómez, Juan Bautista Villalpando's Divine Model in Architectural Theory, in Chora 3: Intervals in the Philosophy of Architecture, eds Alberto Pérez-Gómez and Stephen Parcell 
and Stukeley, and the main premises of Wood's Origin of Building parallel Villalpando's work. What is different, particularly with the work of Stukeley and Wood, is that the origins of architecture were imbedded into the culture of the Druids.

For Newton the importance of Stonehenge as a Prytanæum, the model of Solomon's Temple, was not its national significance, but rather its religious and universal significance. The opposite was true of Jones, Stukeley, and Wood. Although Jones perceived that Stonehenge was not of British invention, the Tuscan order that was built became representative of the civilized Britons. The connection Jones makes with the Temple is more tentative than Newton's, Stukeley's, and Wood's, nevertheless like them he indicated that it was a microcosm of the macrocosm. The fabric of this universality was the Tuscan column, which Jones had made representative of the civilized Britons and, in this way, had become peculiarly British. The Tuscan order fed into the eighteenth-century rise of national identity in Britain. ${ }^{95}$ Tuscan columns were images of strength and Britishness and can be seen in eighteenth-century coats of arms. ${ }^{96}$ William Blake, the great artist and visionary poet, absorbed the architecture, Druid lore, and its Mosaic connections as presented by Stukeley and Wood, and this is reflected in his great poems Jerusalem and Milton. ${ }^{97}$ The poem Milton became the hymn 'Jerusalem' which strengthens English identity even to this day. ${ }^{98}$

Jones, Newton, Stukeley, and Wood all contributed to the knowledge of their age and far beyond, through the significant advances they made in their relative fields. Although their contribution to society had nothing to do with the connections they made between the Temple of Solomon and Stonehenge, their inspiration cannot be separated from their work in this area. Examining their arguments for a connection between the Temple and Stonehenge highlights their attempt to rationalize the mystery of Stonehenge and the Temple. In an age of experimentation, they reconstructed the architecture of one or both of them in their attempt to understand the truth and origins

(Montreal: McGill-Queen's University Press, 1999); Joseph Rykwert, The Dancing Column: On Order in Architecture (Cambridge, MA: MIT Press, 1996), p. 27; George L. Hersey, Architecture and Geometry in the Age of the Baroque (Chicago: University of Chicago Press, 2000), p. 114.

95 See Colley, Britons.

${ }^{96}$ Tessa Morrison, 'Juan Battista Villalpando: Solomon's Temple and the Architectural Metaphor', International Journal of the Humanities, 6 (2008), 203-12 (p. 204).

${ }^{97}$ Blake, Jerusalem, eds Morton D. Paley and David Bindman (Princeton: Princeton University Press, 1997); Blake, Milton a Poem, eds Robert N. Essick and Joseph Viscomi (Princeton: Princeton University Press, 1998).

${ }^{98}$ Blake, Milton, p. 213.

Parergon 29.1 (2012) 
of these monuments. All applied architectural norms in their reconstructions to resolve impossible mysteries. The Age of Reason built on ideas of the past, and what may today appear to have been fantastic flights of fantasy often resulted in very real advances in science, society, and culture.

The School of Architecture and Built Environment The University of Newcastle

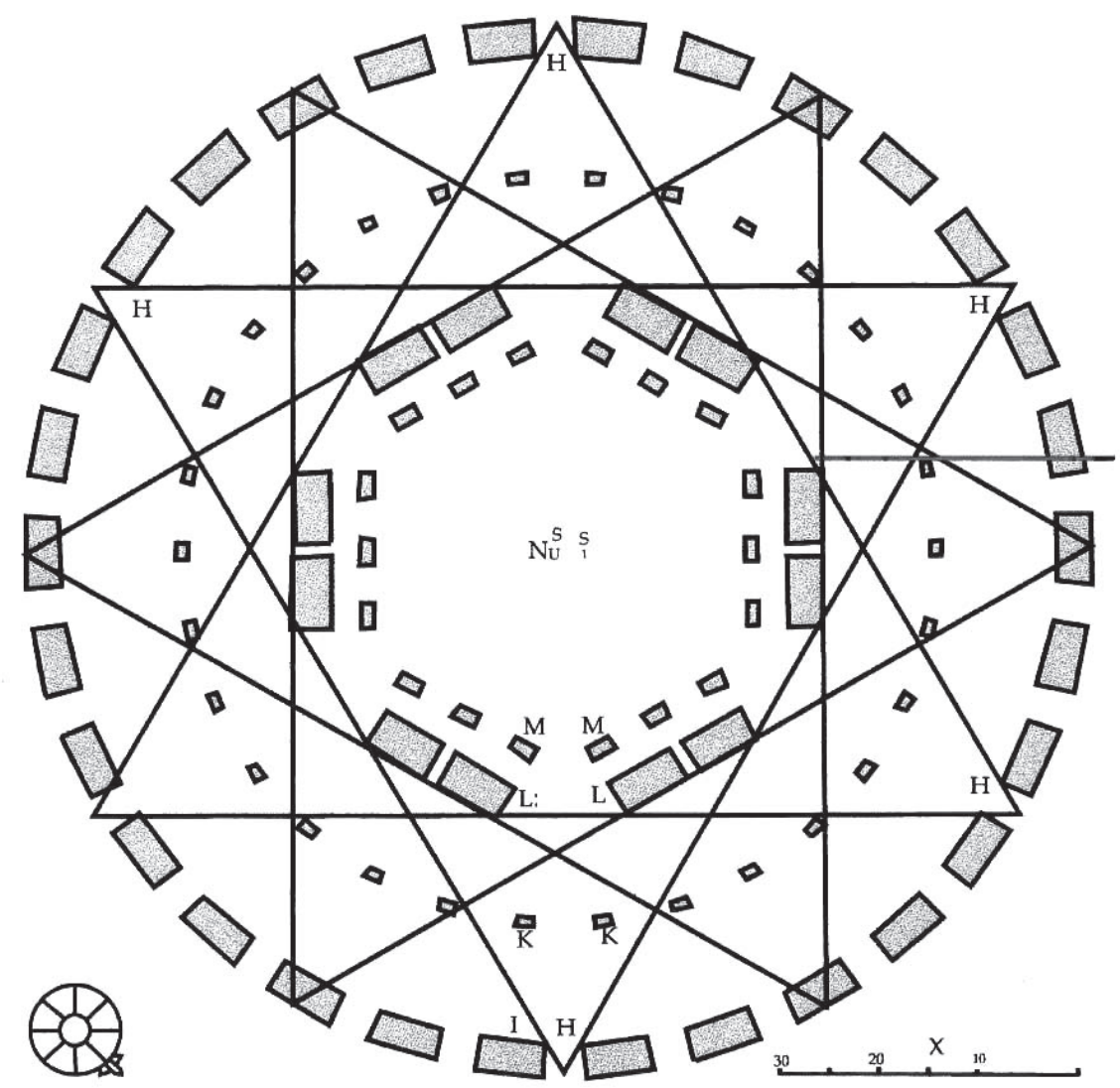

Figure 1

Inigo Jones's architectonical scheme for Stonehenge

Source: Inigo Jones, The Most Notable Antiquity of Great Britain Vulgarly called Stone-Heng on Salisbury Plain Restored (London, 1655), p. 58. (Facsimile drawn by the author) 


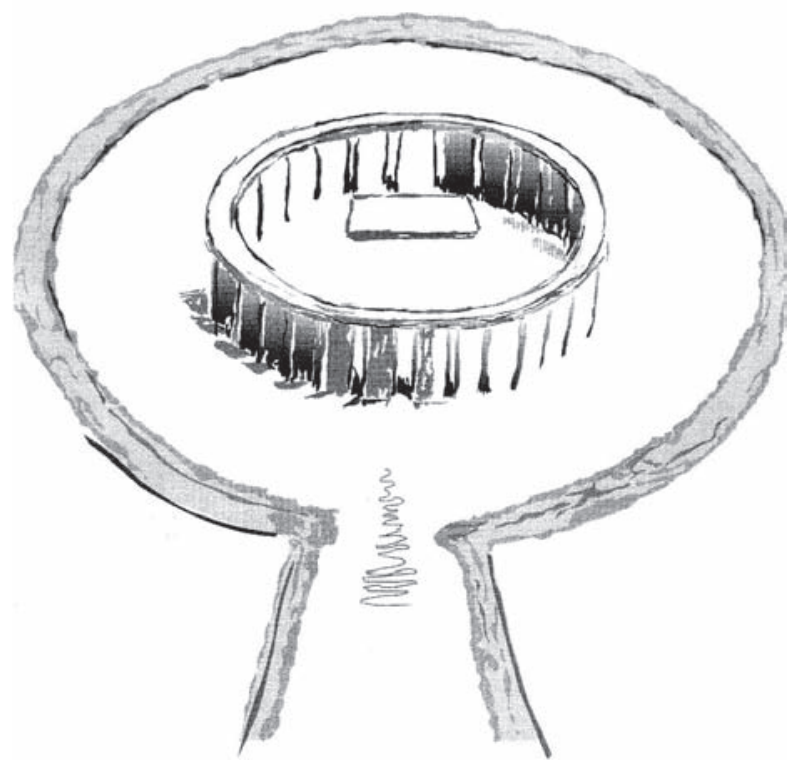

Figure 2

The round form

Source: London, Freemasons Library, William Stukeley, 'The Order of the Pillars of Solomon's Temple', 1760, fol. 7. (Facsimile drawn by the author)

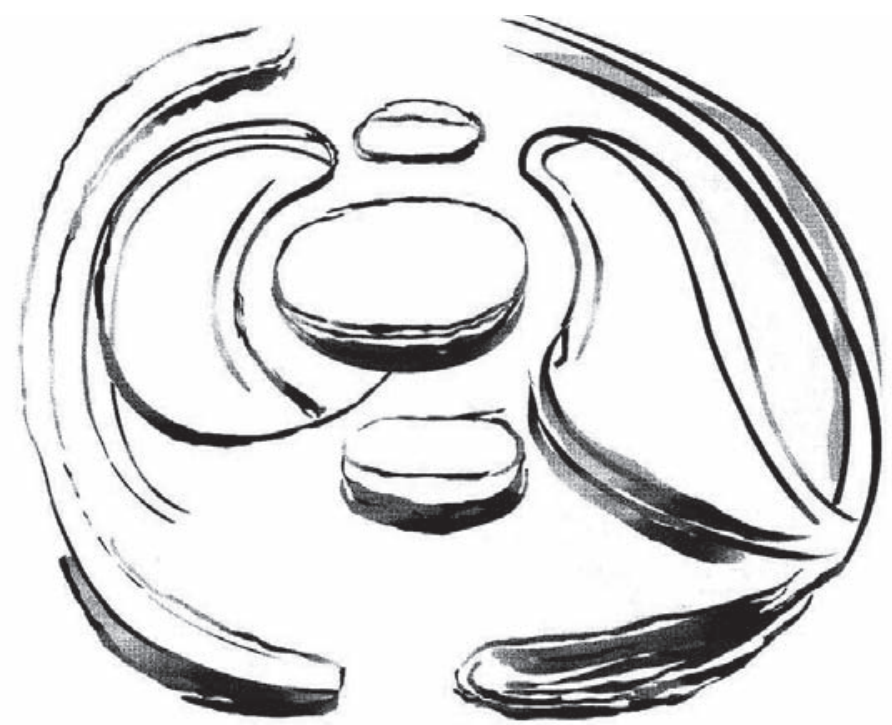

Figure 3

The Alate temple

Source: London, Freemasons Library, William Stukeley, 'The Order of the Pillars of Solomon's Temple', 1760, fol. 3. (Facsimile drawn by the author) 


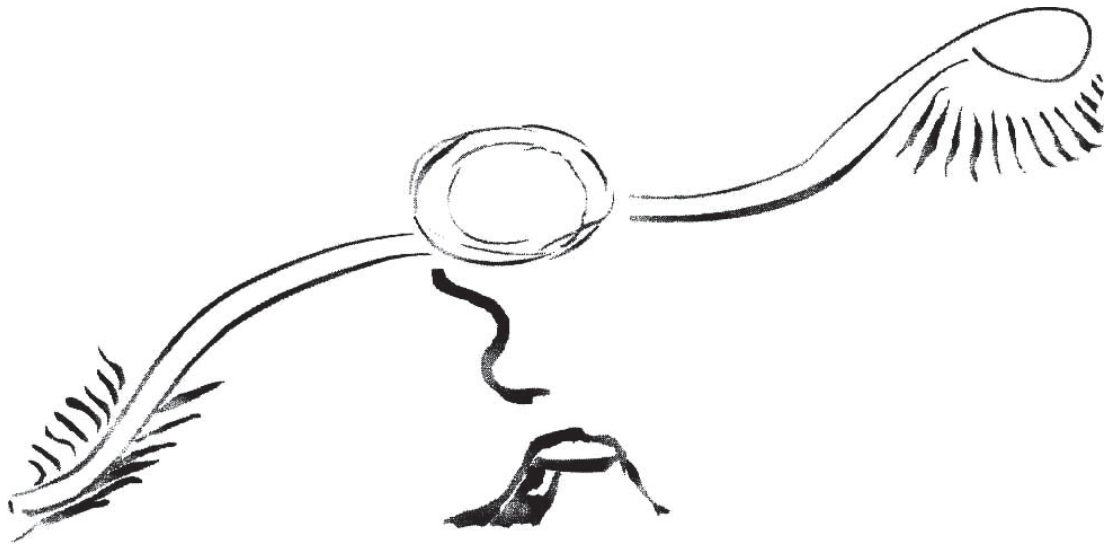

Figure 4

The Dracontium temple

Source: London, Freemasons Library, William Stukeley, 'The Order of the Pillars of Solomon's Temple', 1760, fol. 5. (Facsimile drawn by the author)

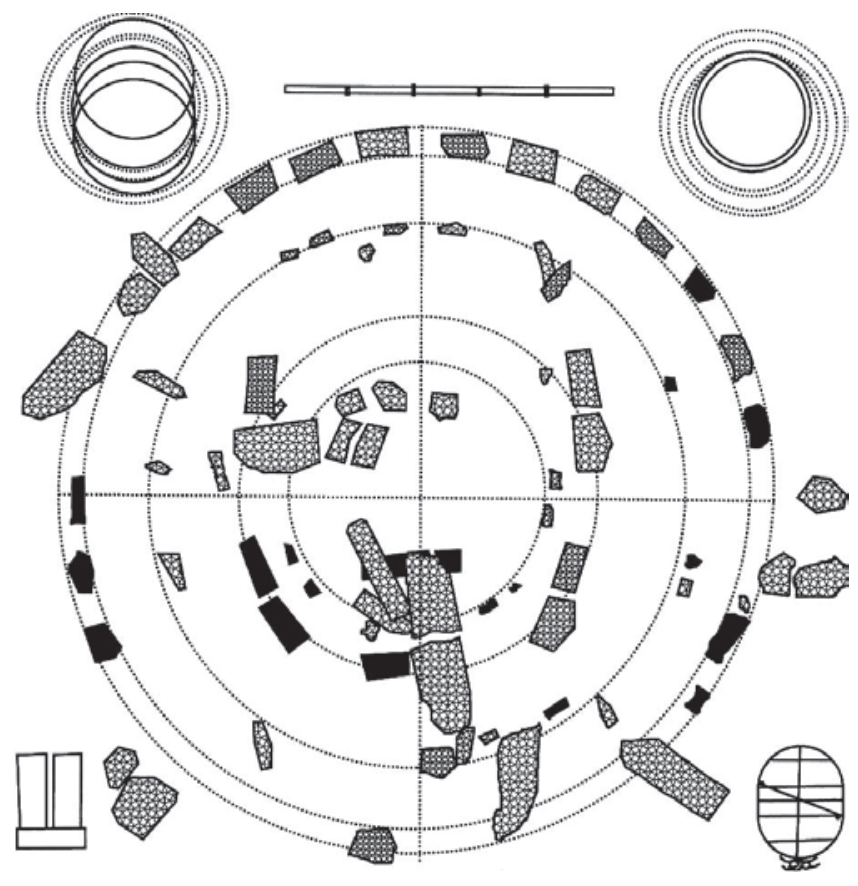

Figure 5

Stukeley's ground plan of his survey of Stonehenge, undertaken in the early 1720 s

Source: Aubrey Burl and Neil Mortimer, eds, Stukeley's Stonehenge:An Unpublished Manuscript 1721-1724 (New Haven:Yale University Press, 2005), unpaginated.

(Facsimile drawn by the author) 


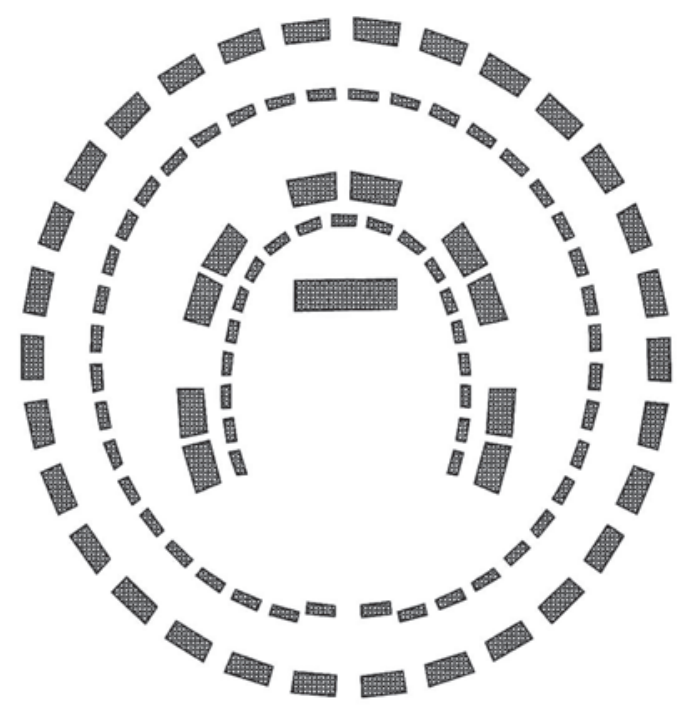

Figure 6

Stukeley's ground plan of his reconstruction of Stonehenge, executed after his survey.

Source: William Stukeley, Stonehenge, a Temple Restor'd to the British Druids (London, 1740), p. 20. (Facsimile drawn by the author)

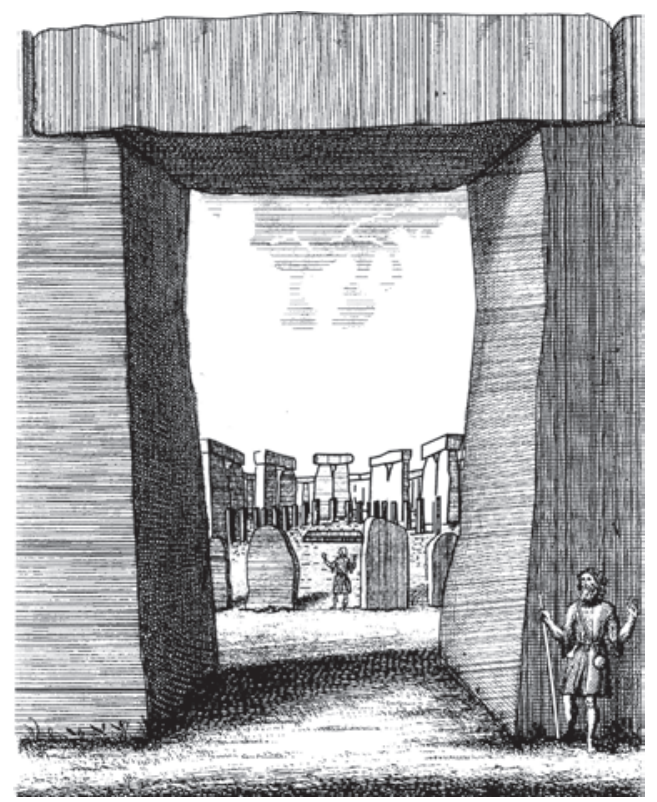

Figure 7

The 'sanctum sanctorum' of Stonehenge

Source: William Stukeley, Stonehenge, a Temple Restor'd to the British Druids

(London, 1740), p. 12. (Facsimile drawn by the author) 


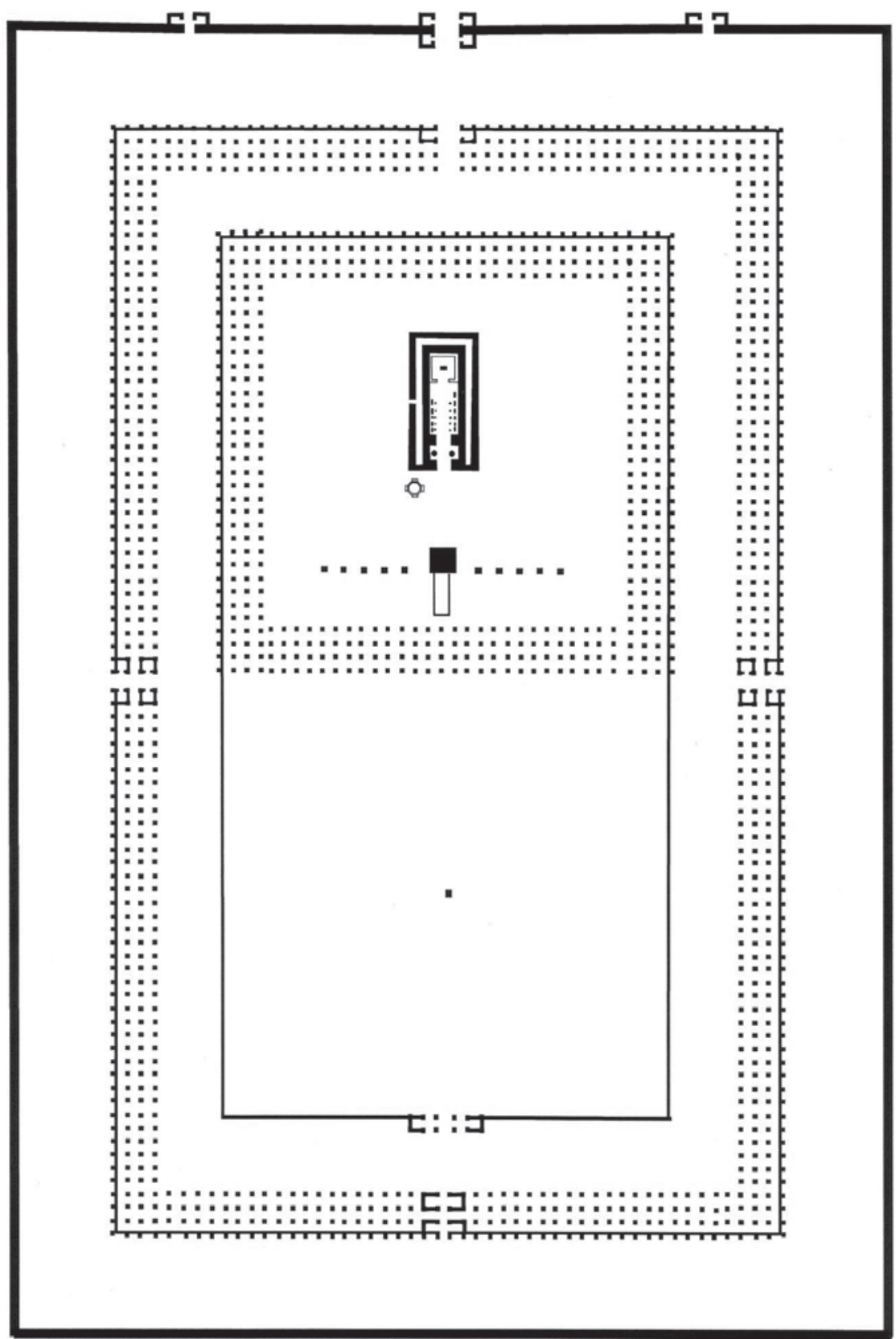

Figure 8

Wood's ground plan for the Temple of Solomon Source: John Wood, The Origin of Building or, the Plagiarism of the Heathens Detected (Bath, 1741), plates $24 \& 25$. (Facsimile drawn by the author) 


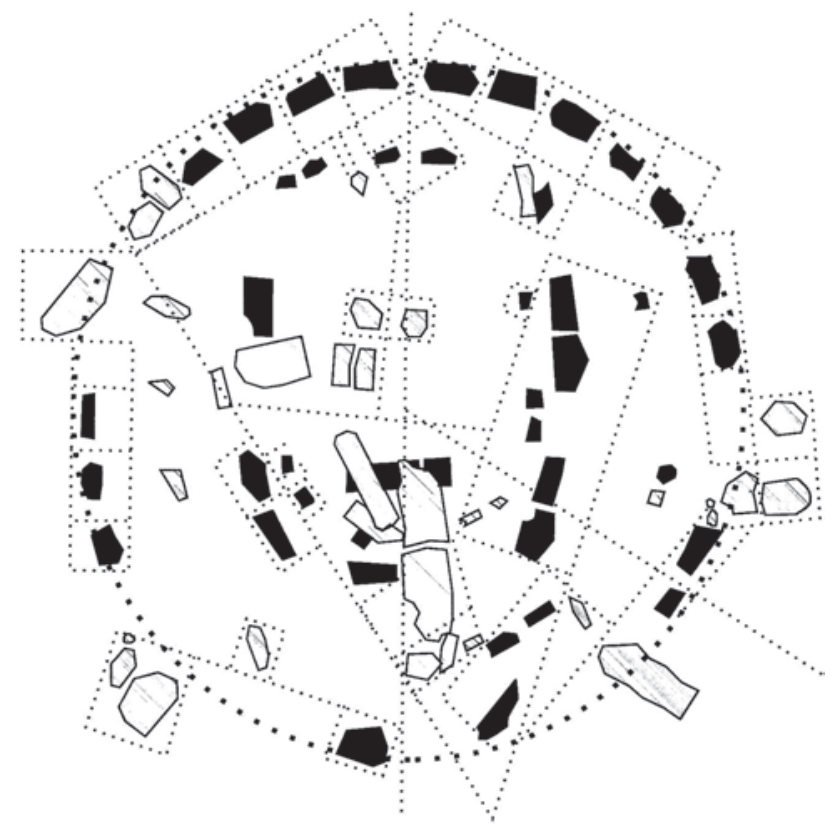

Figure 9

Ground plan of Wood's survey of Stonehenge

Source: John Wood, Choir Gaure, Vulgarly called Stonehenge on Salisbury Plain, Described, Restored and Explained (London, 1749), p. 55. (Facsimile drawn by the author)

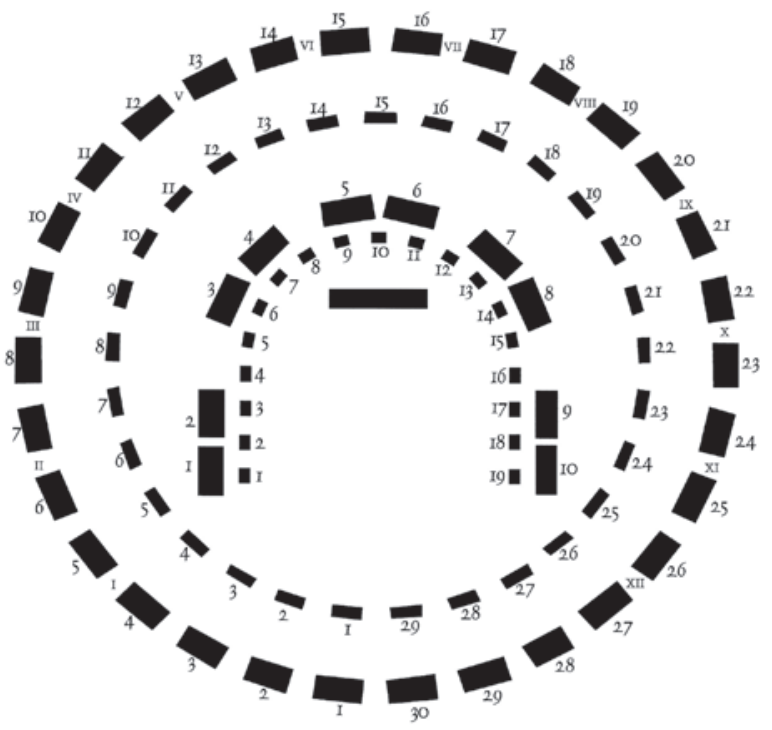

Figure 10

Wood's ground plan of his reconstruction of Stonehenge Source: John Wood, Choir Gaure, Vulgarly called Stonehenge on Salisbury Plain, Described, Restored and Explained (London, 1749), p. 66. (Facsimile drawn by the author) 


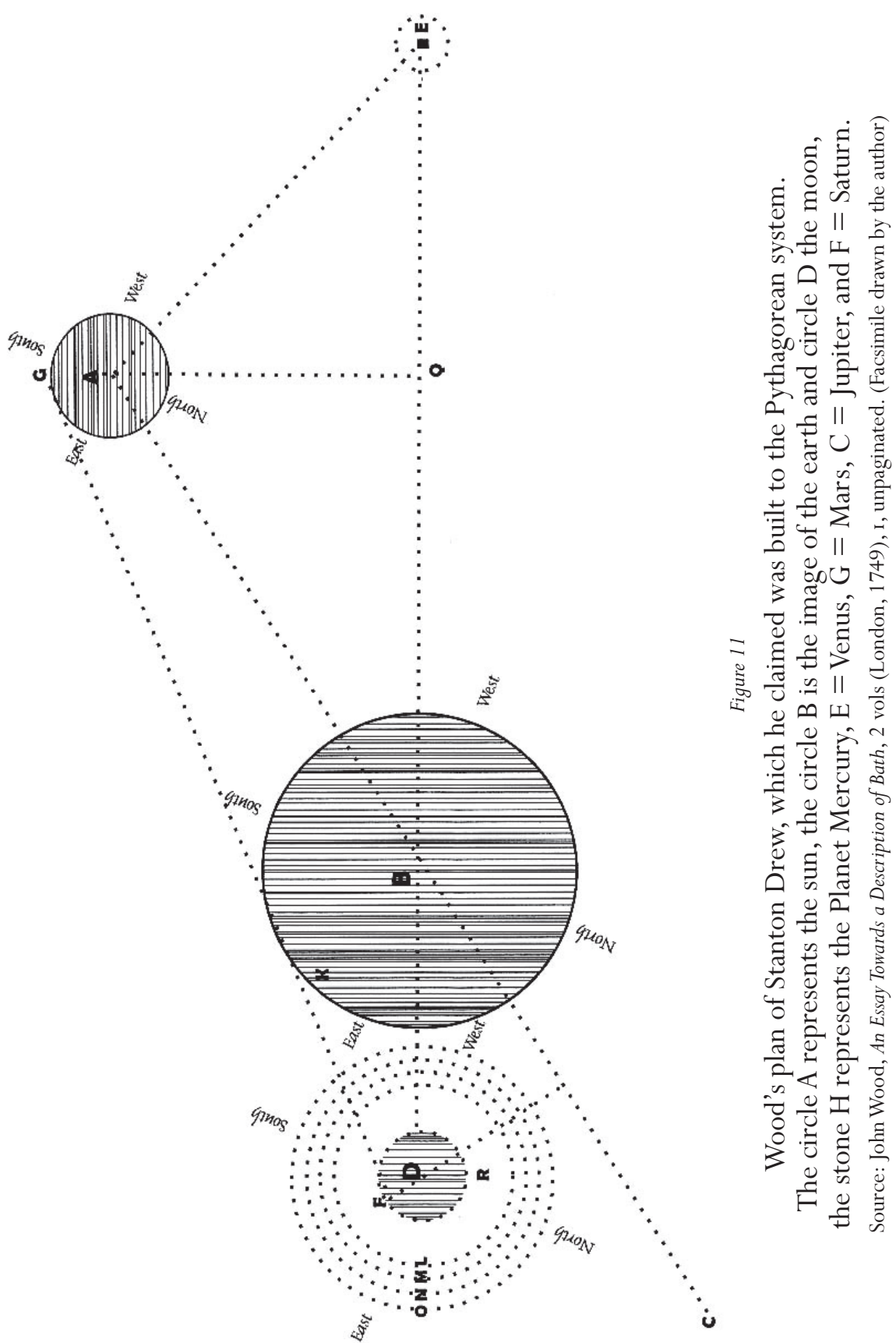

